\title{
USING THE EMERGENCY NOTIFICATION SYSTEM FOR SOCIALLY EXCLUDED PEOPLE ON THE EXAMPLE OF THE DEAF IN POLAND
}

\begin{abstract}
Implemented in Poland since 2011, the emergency notification system is primarily based on direct, telephone, verbal contact between the person making the application and the operator of the emergency number in the Emergency Response Centre (CPR), a police officer in county command, firefighter in county command of the State Fire Service, or by emergency medical dispatcher. It makes that with such assumptions, it becomes unavailable for the deaf. Such people cannot make verbal contact by phone. Even if in your daily life can make the words and communicate with the caller through a direct reading from his lips, then by the inability to hear the telephone becomes impossible. A deaf person can make contact and exchange information either through visual and communication in sign language, or by written communication. In view of the widespread use even among the deaf mobile phones there is a possibility to use for sending alerts short text messages, so-called "SMS." In this article Author presents his experiences and the insights related to the emergency notification and the possibility to use its functionality by people with auditory disability. experiences were collected during an active participation of the author in activities related to the creation of the emergency notification system in Podkarpacie Region and during implementation SMS gateway designed to receive alerts from the deaf from the region in 2014 in the Emergency Notification Centre in Rzeszow.
\end{abstract}

Keywords: Emergency Notification System, ENS, Emergency Notification Centre, ENC, SMS, deaf.

\section{AN ANALYSIS OF THE AREA OF CONSIDERATIONS}

Deafness is a name that identifies a disability involving the inability to receive (hear) the sounds caused by dysfunction of the body. A deaf person is a man to whom the loss or substantial impairment of the hearing analyzer makes it impossible to understand human speech through hearing and for whom in work and all the tasks in life the hearing is of no practical significance ${ }^{2}$. There are many types of deafness and each of them has influence on different aspects of the daily operation of the deaf.

\footnotetext{
${ }^{1}$ Stanislaw J. Rysz, PhD, lecturer at the Rzeszów University of Technology, University of Rzeszow and WSPIA University of Rzeszow; e-mail: stanislaw.rysz@vp.pl.

Dr Stanisław J. Rysz, wykładowca na Politechnice Rzeszowskiej, Uniwersytecie Rzeszowskim i na Wyższej Szkole Prawa i Administracji, e-mail: stanislaw.rysz@vp.pl.

${ }^{2}$ Com. http://pedagogikaspecjalna.tripod.com/notes/deafness.html\#1 (access: 1.12.2014).
} 
People who do not hear from birth function, and otherwise those who have heard for some time, and then, as a result of various factors, they lost hearing.

The first ones are not familiar with the world of sound in general. It does not exist for them. Perhaps the sound of appropriate frequency and energy is felt by them as a specific tremor of structure on which they stand, or touch. But nothing more.

The latter can remember what it is like to be able to hear. Can remember and use the skills and knowledge that they possessed at the time when I heard it. Of course, many in this regard depends on when the hearing loss occurred and how long they could actively participate in the educational process. Their contributing to the daily life is different from participation deaf from birth. This is particularly evident in the use of written language. If you are deaf from birth often have problems with writing and reading sentences and even individual words. Do not pay attention to grammar, and often do not know how to write or $\mathrm{read}^{3}$.

According to the data of the Census of 2011 in Poland ${ }^{4}$ live about 100 thousand of the deaf (com. Table 1). This can be a single dysfunction, but it can also be one of the few, which makes that person face even more difficult challenges in life. The data show that injuries and diseases of hearing organ occur with the same frequency among women and among men. These are people of all ages, but the analysis of the graph shown in Figure 1 shows that among the disabled practically every $7^{\text {th }}$ person has problems with hearing.

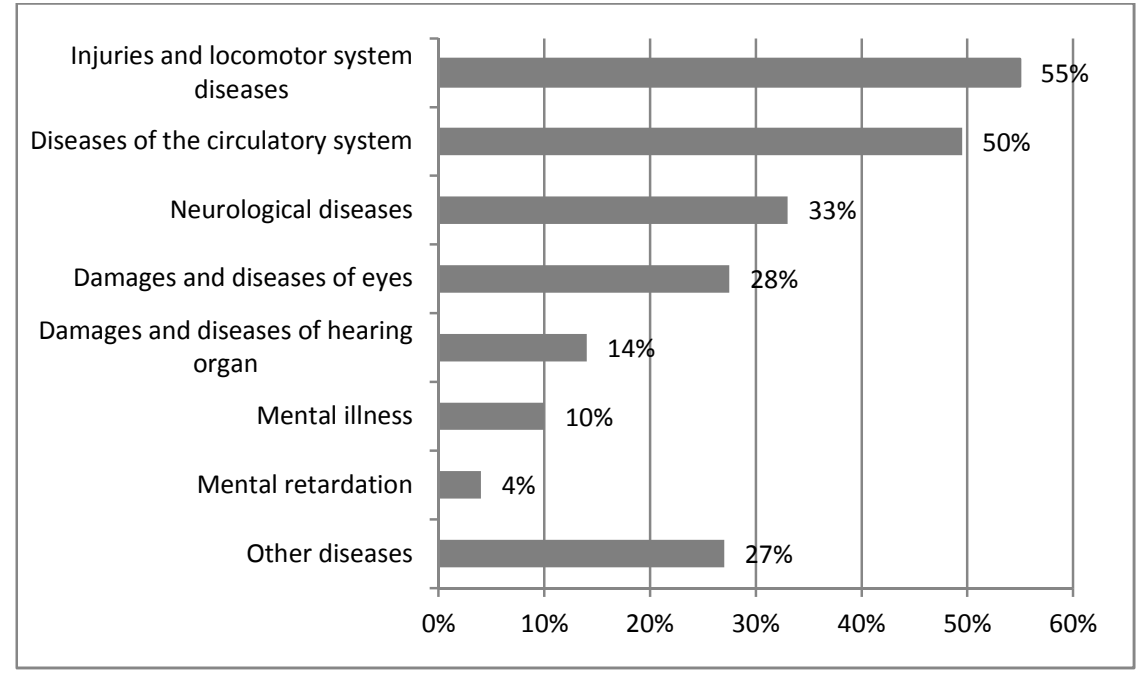

Figure 1. The occurrence of hearing disorders in people with disabilities (in \%)

Source: Own elaboration based on the CSO report data entitled "Health of the Polish population in 2009".

\footnotetext{
${ }^{3}$ It is not the intention of the author to hurt anyone in the scope described in this paper, nor diminish the life skills or accomplishments. It only discusses the problem from the point of view of scientific reliability.

${ }^{4}$ File: osoby_niepelnosprawne_nsp2011.xls, table 9(15), source: http://www.niepelnosprawni. gov.pl/niepelnosprawnosc-w-liczbach-/dane-demograficzne/informacje-i-dane-demograficzne/ (access: 3.12.2014).
} 
Using the emergency notification system...

Table 1. Deaf population in Poland, broken down by economic groups and performance limitations

\begin{tabular}{|l|r|r|r|r|r|}
\hline \multirow{2}{*}{ Number of the deaf: } & In total & \multicolumn{1}{|c|}{ Men: } & Women: & City: & Village: \\
\cline { 2 - 6 } & $\mathbf{9 8} 981$ & $\mathbf{5 4 1 3 9}$ & $\mathbf{4 4 ~ 8 4 2}$ & $\mathbf{6 5 4 8 7}$ & $\mathbf{3 3 4 9 4}$ \\
\hline According to economic groups & \multicolumn{5}{|l|}{} \\
\hline Pre-production & 8856 & 5099 & 3756 & 4963 & 3892 \\
\hline Production & 43978 & 26943 & 17035 & 28804 & 15174 \\
\hline Post-production & 46147 & 22097 & 24050 & 31720 & 14427 \\
\hline $\begin{array}{l}\text { According to performance limita- } \\
\text { tions: }\end{array}$ & \multicolumn{5}{|l}{} \\
\hline total & 5203 & 2821 & 2382 & 3053 & 2150 \\
\hline serious & 18195 & 9896 & 8299 & 12171 & 6024 \\
\hline moderate & 75583 & 41422 & 34161 & 50264 & 25320 \\
\hline
\end{tabular}

Source: Own elaboration based on data obtained from the Office of the Government Plenipotentiary on Persons with Disabilities 5 .

In fact, the situation is much more onerous by the fact that the hearing disability is often accompanied by another, which brings additional difficulties. Particularly difficult is the situation of people who neither hear nor see.

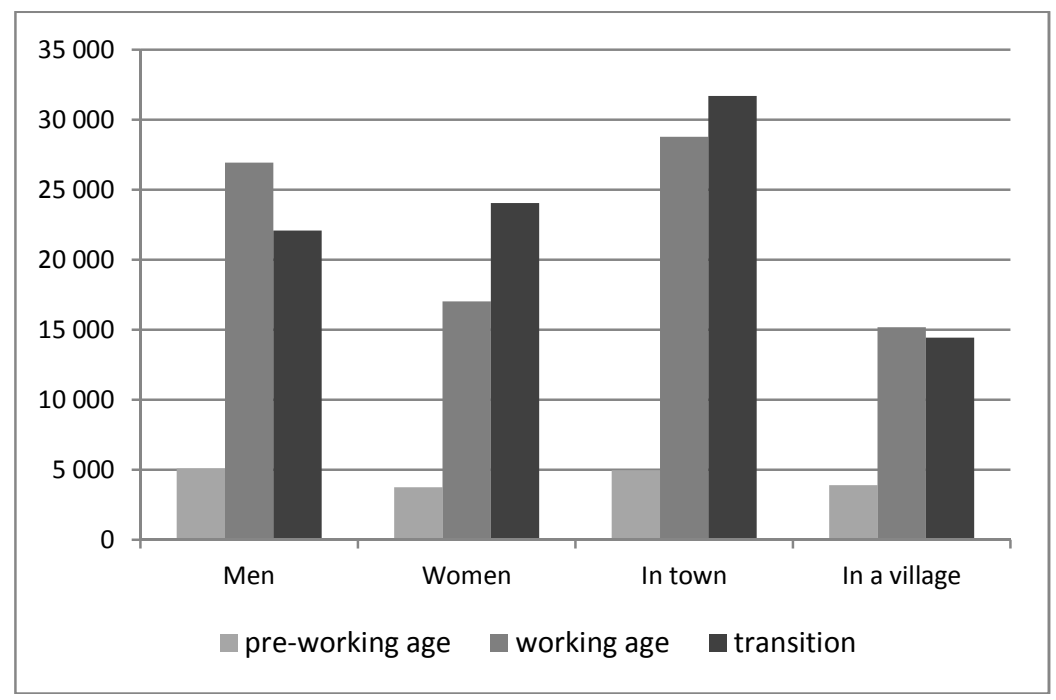

Figure 2. The age breakdown of the population of the deaf by economic groups

Source: Own elaboration of the Author.

${ }^{5}$ Com. http://www.niepelnosprawni.gov.pl/niepelnosprawnosc-w-liczbach-/dane-demograficzne/informacje-i-dane-demograficzne/ (access: 3.12.2014). 


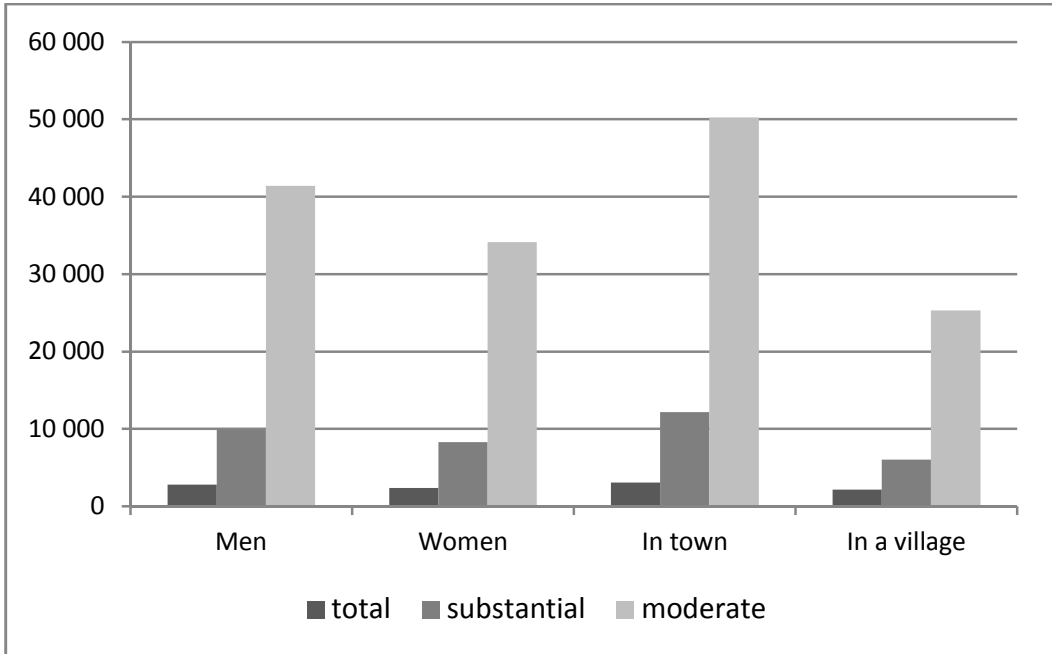

Figure 3. Breakdown of the deaf population due to the degree of deafness Source: Own elaboration of the Author.

Table 2. People with hearing disabilities aged 15 years or more. The division depending on the degree of disability

\begin{tabular}{|l|c|c|c|c|c|c|c|c|c|c|}
\hline Specification & In total & $\begin{array}{c}\mathbf{1 5 - 1 9} \\
\text { years } \\
\text { old }\end{array}$ & $\begin{array}{c}\mathbf{2 0 - 2 9} \\
\text { years } \\
\text { old }\end{array}$ & $\begin{array}{c}\mathbf{3 0 - 3 9} \\
\text { years } \\
\text { old }\end{array}$ & $\begin{array}{c}\mathbf{4 0 - 4 9} \\
\text { years } \\
\text { old }\end{array}$ & $\begin{array}{c}\mathbf{5 0 - 5 9} \\
\text { years } \\
\text { old }\end{array}$ & $\begin{array}{c}\mathbf{6 0 - 6 9} \\
\text { years } \\
\text { old }\end{array}$ & $\begin{array}{c}\mathbf{7 0 - 7 9} \\
\text { years } \\
\text { old }\end{array}$ & $\begin{array}{c}\text { 80 years } \\
\text { old and } \\
\text { more }\end{array}$ \\
\hline $\begin{array}{l}\text { Marking of the groups } \\
\text { on diagrams: }\end{array}$ & 1 & 2 & 3 & 4 & 5 & 6 & 7 & 8 \\
\hline \multicolumn{7}{|c|}{ Hearing the talk with several people (in thousand) } \\
\hline $\begin{array}{l}\text { without any } \\
\text { difficulty }\end{array}$ & 25075,4 & 1909,9 & 4846,9 & 4797,0 & 4125,2 & 4729,4 & 2701,9 & 1497,0 & 468,1 \\
\hline $\begin{array}{l}\text { with some } \\
\text { difficulty }\end{array}$ & 2411,8 & 19,8 & 88,3 & 104,9 & 163,7 & 433,8 & 487,8 & 690,8 & 422,7 \\
\hline $\begin{array}{l}\text { with high } \\
\text { difficulty }\end{array}$ & 478,3 & 2,4 & 4,1 & 5,3 & 27,0 & 67,1 & 77,2 & 132,4 & 162,8 \\
\hline does not hear & 45,7 & & 1,1 & 0,7 & 3,4 & 5,5 & 7,9 & 12,5 & 14,5 \\
\hline no data & 35,9 & & 4,1 & 0,8 & 6,6 & 10,0 & 10,2 & 2,7 & 1,4 \\
\hline & 1032,7 & 54,2 & 132,8 & 116,4 & 100,8 & 166,6 & 112,6 & 178,0 & 171,4 \\
\hline yes & 30887,3 & 2391,9 & 5942,5 & 5524,2 & 4732,7 & 5602,5 & 3358,4 & 2296,3 & 1038,8 \\
\hline no & 73,1 & 0,2 & 0,9 & 4,0 & 0,2 & 10,6 & 7,4 & 25,3 & 24,5 \\
\hline $\begin{array}{l}\text { deaf or almost } \\
\text { not hearing } \\
\text { person }\end{array}$ & $7,2,2$ & - & 1,3 & 0,7 & - & - & - & 0,3 & - \\
\hline no data & 2,2 &
\end{tabular}

Source: Own elaboration based on the CSO report data ${ }^{6}$ entitled "Health of the Polish population in 2009".

${ }^{6}$ Report published on: http://old.stat.gov.pl/cps/rde/xbcr/gus/ZO_stan_zdrowia_2009.pdf, p. 265 (access: 3.12.2014). 
The number of the specified group of persons with disabilities (also known as "deafblind" or "blind-deaf") in Poland is estimated, depending on the source ${ }^{7}$, from about 2 thousand $^{8}$ to about 7 thousand 9 of people.

Analysis of the data presented in Table 2 presented graphically on the ,radar” graphs ${ }^{10}$ on Figure 2 illustrates the specificity of one aspect of deafness. The issue concerns the possibility of hearing and understanding the conversation in the immediate vicinity of the deaf person by several people.

The axes of graphs define the study population group aged:

$1-<15,20)$ years old,

$2-<20,30$ ) years old,

$3-<30,40)$ years old,

$4-<40,50)$ years old,

$5-<50,60)$ years old,

$6-<60,70)$ years old,

$7-<70,80)$ years old,

$8-80$ and more years old.

The graphs show that with the age of the subjects the hearing performance and opportunities to hear and understand ${ }^{11}$ the interlocutor deteriorate.

Old age brings with it a significant deterioration in the life efficiency of a person ${ }^{12}$. It is natural and in most cases accepted. However, in comparison with a disability phenomenon is much more severe and noticeable. A person who is experiencing the limitations related to their body, in a special way realizes their potential's deterioration.

7 The author draws the attention to the low reliability of the data used to develop guidelines for programs, projects, activities, or any kind of initiatives for the environment of the deaf-blind people.

8 Com. Guidance on the implementation of support for the socially excluded and disadvantaged under the Operational Programme Human Capital Department of ESF Management at the Ministry of RD, Warsaw, October 2009, p. 83, source: http://www.efs.gov.pl/dzialaniapromocyjne/Documents/Poradnik_dot_realizacji_wsparcia_dla_os_wykluczonych_spol_POKL_091009.pdf (access: 05.12.2014).

9 Com. Report about people with disabilities in Poland, Congress of Women Press Office, Warsaw, 06.06.2011, source: $\mathrm{http}: / /$ www.google.pl/url?sa=t\&rct=j\&q=\&esrc=s\&source=web\&cd=1\&cad= rja\&uact=8\&ved=0CCAQFjAA\&url=http $\% 3 \mathrm{~A} \% 2 \mathrm{~F} \% 2 \mathrm{Fsamorzad}$. pap.pl $\% 2 \mathrm{Fpalio} \% 2 \mathrm{Fhtml}$. run\%3F_Instance\%3Dsamorzad_nowy.pap.p1\%26_PageID\%3D6\%26_media_id\%3D57272\% 26_filename\%3DKK_2011_06.06_raport_o_niepelnosprawnych.pdf\%26_mimetype\%3 Dapplication\%2Fpdf\%26_CheckSum\%3D780010585\&ei=97eBVLGvOcriaurFgZAG\&usg= AFQjCNH9iyEusFxMmurTwzezqyJHR42CzA\&bvm=bv.80642063,d.d2s (access: 3.12.2014).

${ }^{10}$ The graphs present the issue in a qualitative, not quantitative approach.

11 Shown in Figure 4 a) improvement of hearing for the study population aged 20 to 60 years old may be associated directly with the experience gained over the years that manifests in the ability to read the contents of speech from lips. Synergistic use of incomplete hearing and reading from the lips may manifest itself in a subjectively significant increase in the possibility of hearing the conversations in the immediate vicinity. It is only the thesis of the author and cannot be regarded as measurably proven theorem.

12 The graphs confirm that the hearing performance deteriorates with age. 
In case of deaf people, it also manifests itself through negative correlation of possibilities $^{13}$ and skills ${ }^{14}$.

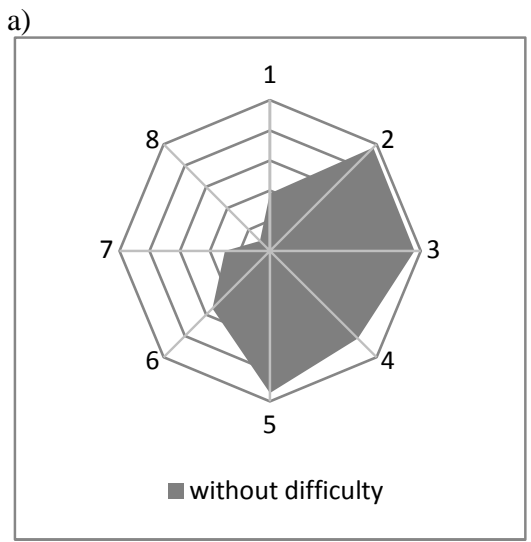

c)

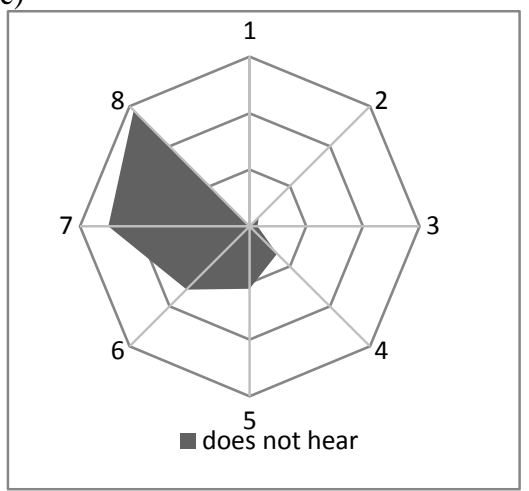

b)

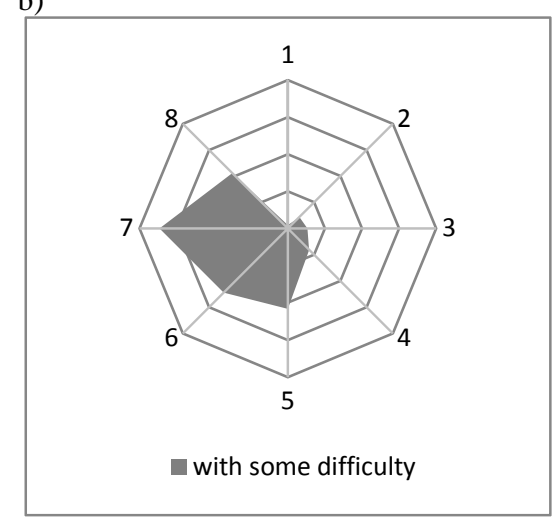

d)

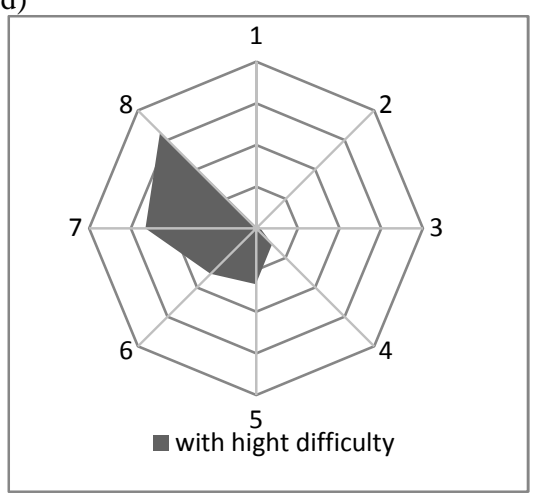

Figure 4. Qualitative analysis of data on the efficiency of the hearing, depending on the age of the respondents

Source: Own elaboration of the Author.

Particularly important for the development of social skills of deaf people are: the optimal treatment ${ }^{15}$ and appropriate, adapted to the cognitive possibilities education.

${ }^{13}$ Due to the deteriorating physical dexterity it is more and more difficult for older deaf people to actively use the sign language and fully participate in this form of social life in the environment. There are also troubles with the use of modern equipment, such as computer, phone etc.

${ }^{14}$ Deaf people, especially those who have never heard, have trouble with reading and writing long sentences. With age, the problem may be exacerbated. It results also from the fact that the educational activities in which such persons have participated during their childhood and adolescence, often do not bring the intended effects.

15 Particular attention should be paid to the hearing organ prosthesis with, for example cochlear implants. Com. Consensus on the treatment of hearing loss using implants anchored in the bone, source: http://www.otolaryngologia.org.pl/orl2/pdf/konsensus_leczenie_niedosluchow_implanty_ zakotwiczone.pdf (access: 12.12.2014). 
The need to view things from the perspective of children and young people is extremely important given that it is then when the deaf people are most actively involved in the processes of teaching and their social future depends largely on the quality of these processes ${ }^{16}$.

Table 3. Number of children with hearing disability - sectional summary

\begin{tabular}{|l|c|c|c|c|c|c|}
\hline \multicolumn{1}{|c|}{ Specification: } & Girls & Boys & In total & $\begin{array}{c}\mathbf{0 - 4} \\
\text { years old }\end{array}$ & $\begin{array}{c}\mathbf{5 - 9} \\
\text { years old }\end{array}$ & $\begin{array}{c}\mathbf{1 0 - 1 4} \\
\text { years old }\end{array}$ \\
\hline $\begin{array}{l}\text { The number of } \\
\text { children with serious } \\
\text { trouble and hardship } \\
\text { associated with hearing } \\
\text { (in thousand) }\end{array}$ & 22,9 & 46,2 & 69,1 & 12,9 & 37,9 & 18,4 \\
\hline
\end{tabular}

Source: Own elaboration of the Author ${ }^{17}$.

\section{OUTLINE OF THE LEGAL SITUATION}

The Act of November 22, 2013 on emergency notification system ${ }^{18}$ defines the emergency notification as information on the occurrence or suspicion of a sudden threat to life or health, including an act of violence, as well as the sudden threat to the environment or property and threats to public safety and order, directed to the numbers supported by the emergency notification system, by the provider of publicly available telephone services, from external monitoring systems or with the use of means of communication that allow the immediate transfer of this information to the emergency center. The phrase: directed to the numbers supported by the emergency notification system $^{19}$, by the provider of publicly available telephone services invariably suggests that the main way of transmitting such information by persons who have found themselves in the face of threat to life, health, the environment or property will be a phone call. Such an assumption is simple and fits well with the interpersonal possibilities of vast majority of people.

However, there is a part of the population, which as a result of this assumption, without its own share, is excluded from the total authorized to report to the state the information about the need for help and the use of some of the safety and security services ${ }^{20}$. These are deaf and deaf-mute people for whom verbal communication with the phone is indeed difficult, and in most cases even unavailable. Even people who have direct contact with the caller are able to articulate their issues and read from the lip movements the speech of interlocutor, in combination with the phone they become powerless: they can talk without knowing whether they are listened to and understood, and not hearing what someone is trying to say to them.

${ }^{16}$ Com. T. Piekot, Report on focused research - professional identity of the deaf and their problems in the labor market, Project co-financed by EU within EFS, proj. no. WND-PKOL.06.02.00-02109/11, source: http://www.glusiwpracy.dobrekadry.pl/dokumenty/Opracowanie_jakosciowe.pdf (access: 15.12.2014 r.)

17 Com. ibidem, p. 152.

${ }_{18}$ See Journal of Laws of 2013 item 1635, art. 2 point 1).

19 Emergency Notification System in polish: System Powiadamiania Ratunkowego (SPR).

${ }^{20}$ As services concerning the provision of security the author perceives in the first place the provisions of emergency medical services (PRM), fire protection (PSP), ensuring public safety (Police). 
From the point of view of society, a citizen, his duties, but also its rights, it is a kind of social exclusion, understood as lack or limitation of opportunities to participate, influence and use of basic public institutions and markets, which should be available to everyone, especially for the poor ${ }^{21}$. ${ }_{\text {Here }}$ there is no question of the intended action of anyone, operations which would intend to cause such a situation. However, the very specific nature of the peculiar "award", a kind of alienation of a deaf person from the world around her results in the fact that without adequate support, that person herself will not benefit from some of their rights, facilities and services.

Countries - parties to the adopted ${ }^{22}$ by the United Nations (UN) on December 13, 2006 Convention on the Rights of Persons with Disabilities ${ }^{23}$ in art. 4 par. 1 let (f) undertake to: "undertake or promote research and manufacture and ensure the availability and use of goods, services, equipment and facilities universally designed, as defined in Art. 2 of the Convention, which should require the smallest possible adjustments and incur the least cost to meet the special needs of people with disabilities; and also undertake to promote the principles of universal design when establishing standards and guidelines".

The above mentioned "»universal designing « means the designing of products, environment, programs and services in such a way as to be usable by all people, to the greatest extent possible, without the need for adaptation or specialized design. »Universal design « does not exclude assistive devices for particular groups of persons with disabilities, if needed" 24 . This means that the described in the Act of November 22, 2013 on Emergency notification system ${ }^{25}$ tools and procedures for reporting incidents and threats to the safety of people, property, the environment, etc. should be planned and implemented so as to give the possibility of using also to the deaf. This is especially strongly emphasized in the Act of August 19, 2011 on the sign language and other means of communication ${ }^{26}$, which in art. 4 par. 1. states that: "An entitled person [deaf, deaf-blind - note of the Author] has the right to the free use of the chosen forms of communication".

The legislature is consistent here and later, in art. 9 par. 1. states that: "The public administration authority is obliged to provide a service allowing for communication". The statement is clear - the authority is required. This means that in the emergency notification system it is necessary to create such a channel that allows certain, immediate, real-time effective contact of deaf person with entities appointed to provide assistance.

The specificity of the emergency notification requires that the person making the notification on the need for emergency action, in addition to the description of the event or occurring risk, also informs about the place where the help is needed. Having regard to the peculiarity of the situation, the emotions and the accompanying stress, it must be assumed that the circumstances are not conducive to communication. In the event of notification by

${ }^{21}$ Definition taken from the National Social Inclusion Strategy for Poland, p. 21, source: http://www.mpips.gov.pl/gfx/mpips/userfiles/File/mps/NSIS.pdf (access: 1.12.2014).

22 Contents of the document Convention on the Rights of Persons with Disabilities is available on the website: http://www.niepelnosprawni.gov.pl/dokumenty-miedzynarodowe-/dokumenty-organizacji-narodow-zj/konwencja-o-prawach/, (available: 3.12.2014).

${ }^{23}$ The Convention on the Rights of Persons with Disabilities has been ratified by the President on September 6, 2012 under the Act of June 15, 2012 on the ratification of the Convention on the Rights of Persons with Disabilities (Journal of Laws, item 882).

${ }^{24}$ Com. Convention on the Rights (...), quoted art. 2.

25 Journal of Laws of 2013, item 1635.

${ }^{26}$ Journal of Laws of 2011, No. 209. item 1243. 
a deaf person, the intensity of stressors described above will be even bigger and the quality of the message can be thus significantly devalued. In order to avoid such a situation, in the Act of July 16, 2004 Telecommunications $\mathrm{Law}^{27}$, art. 78 sets out the principles on which telecom operators provide in real-time ${ }^{28}$ the data on the geographical location ${ }^{29}$ of the device of end user of ${ }^{30}$ publicly available telecommunications services.

Unfortunately, the above described principles of cooperation of entities introduce an agency element to $\mathrm{it}^{31}$ in form of the President of $\mathrm{UKE}^{32}$. It does not improve the dynamics of the actions taken and is not intended in any way to improve the efficiency and accuracy of the positioning of persons calling and sending short messages to emergency call centers in different provinces.

\section{CONCLUSION}

In this article, the author attempts to show the legal environment, the size and characteristics of the deaf community as an area from which the emergency notification system can and should obtain emergency calls.

One may get the impression that the Polish state is between, on the one hand, the requirements arising from ratified international instruments and regulations adopted to organize the Polish law in this area, and on the other the difficulties that generate further attempts to fulfill the obligations imposed on them by the described legal acts.

The latter can be divided into several groups: organizational problems, technical difficulties and financial shortcomings. Each of these groups requires the right attitude and proper idea.

Since Poland's accession to the European Union, and especially since 2011, emergency call service in Poland is evolving in the direction of reducing the number of emergency numbers, to which such calls can be addressed and tends to direct all emergency and service calls within a reasonable timeframe to general European emergency number $112^{33}$.

27 Journal of Laws of 2004, No. 171. item 1800, as amended.

${ }^{28}$ Com. ibidem, art. 78 par. 1. point 2).

${ }^{29}$ Com. ibidem, art. 78 par. 3. point 2).

30 The term "end user device" is to be understood as both a mobile phone, as well as all kinds of ICT equipment, which in their activities use the data sent over cellular networks.

${ }^{31}$ Public telecommunications network operator is obliged to provide the President of UKE with free information on the location of the network termination, from which an emergency call was made. See ibidem, art. 78 par. 1 .

32 President of UKE - President of the Office of Electronic Communications - is the regulatory body in the scope of telecommunication and postal activity, frequency resources management and control of compliance with the requirements relating to electromagnetic compatibility. It is also a specialized body for the control of devices emitting or liable to emit electromagnetic fields, including telecommunication equipment and devices introduced on the market in Poland. Com. http://www.uke.gov.pl/urzad-805 (access: 15.12.2014)

33 Although the Act on the emergency notification system in art. 3 states that emergency calls can also be directed to domain numbers (999 - Emergency medical services, 998 - State Fire Service and 997 - Police) and service numbers of commercial entities that choose to sign an appropriate agreement with the governors (991, 992, 993, 994 and 987 and others), the in the art. 29 par. 1 point 3 ) it clearly defines the conditions under which the service of domain emergency numbers will be taken over by CPR. At the same time, the promotion of the general European emergency number 112 is evident. 
Financial issues are critical in the implementation of the project, which is building the emergency notification system in Poland. The formula assumes that the SPR is built on a centralized manner, managed by the minister responsible for public administration ${ }^{34}$, and public-safety answering point (PSAP) ${ }^{35}$ in the field are formed by proper heads of provinces.

Technical and technological issues of the implemented concept relate to a wide range of associated fields. The basis is the available, simple and reliable telephone communication with emergency center. This way the majority of emergency calls will be directed from people in the face of danger. Another element is the efficient, accurate and effective PSAP ICT infrastructure. Its task will be to provide the operator of emergency numbers ${ }^{36}$ as much data, as soon as possible ${ }^{37}$ needed to take proper rescue or service action. Another requirement is adequate communication between the described above PSAP infrastructure and field systems of particular authorities and commercial services. Another important issue is the secure, fast and efficient network for teletransmission that will be used to exchange information.

An important element ordering the organizational space of service of emergency numbers is the Act of November 22, 2014 on emergency notification system. Its contents includes fundamental definitions, the outline of the structure and the entities responsible and scope of their responsibility. Not without significance are also the threshold dates that determine the deadlines of implementation of the next steps of the emergency notification system construction in Poland.

From the point of view of the environment of the hearing-impaired individuals, of particular importance is art. 20 par. 1 point 2) let. b), which states that ${ }^{38}$ : "The provider of publicly available telephone services provides the direction of short text messages (SMS) to the emergency numbers $112,997,998$ and 999 to the locally competent emergency center and connection to other emergency numbers to the locally competent units of services legally established to provide help".

Unfortunately, the act has little to do with the reality. The Act of November 22, 2013 on emergency notification system in force since January 1, 2014, but the above cited provision, so far, still functions only in writing...

Until the completion of writing of this article, the author could not obtain from the Ministry of Administration and Digitization any declarations as to the date of implementation of this functionality in the ICT system supporting emergency numbers operators in CPR. This means that by the time of start of the service, receiving emergency notifications in SPR by means of SMS channel, one can have recourse in this respect with the properly elaborated SMS gateways and procedures, which, though temporarily, do pose such a possibility.

${ }^{34}$ Com. Act on the emergency notification system, quoted art. 4.

35 PSAP in polish: Centrum Powiadamiania Ratunkowego (CPR).

${ }^{36}$ Operator of Emergency Numbers in polish: Operator Numerów Alarmowych (ONA).

37 This is primarily about the specification of the location from where the emergency calls are forwarded. Such functionality of the emergency notification system allows to avoid misunderstandings and ambiguities that may arise as a result of lack of knowledge of the place of the incident by the person who reported the incident (e.g. the accident, which happened at night, in the middle of the forest, on the road or in the area which the person reporting does not know and does not recognize).

${ }^{38}$ Com. Act on the emergency notification system, quoted art. 20. 
This is important not only for the deaf. Thanks to its advantages, this form of reporting the need for help from the relevant services can be used in situations involving e.g. domestic violence, kidnapping, imprisonment or terrorist attack.

\section{REFERENCES}

\section{Books and articles}

1. Grocki R., Osoby niepetnosprawne w sytuacji zagrożenia, DIFFIN, Warsaw 2014.

\section{LEGAL ACTS}

2. Act of November 23, 2013 on emergency notification system (Journal of Laws of 2013 item 1635).

3. Act of August 11, 2011 about sign language and other means of communication (Journal of Laws of 2011 No. 209 item 1243).

4. Act of July 16, 2004 Telecommunication Law (Journal of Laws of 2004 no. 171 item 1800, as amended).

5. Act of August 24, 1991 on fire protection (Journal of Laws no. 191, item 1410, as amended).

6. Act of September 6, 2006 on State Emergency Medical Services (Journal of Laws of 2006 no. 191 item 1410, as amended).

7. Act of January 23, 2009 about head of province and government administration in the province (Journal of Laws of 2009 no. 31 item 206, as amended).

8. Act of June 15, 2012 on the ratification of the Convention on the Rights of Persons with Disabilities, (Journal of Laws item 882).

9. Directive 2002/22/EC of the European Parliament and of the Council of March 7, 2002 on universal service and users' rights related to networks and electronic communications services (Universal Service Directive) (OF EU L of April 24, 2002).

\section{INTERNET SOURCE}

1. Convention on the Rights of Persons with Disabilities, source: http://www.niepelnosprawni. gov.pl/dokumenty-miedzynarodowe-/dokumenty-organizacji-narodow-zj/konwencja-oprawach/ (access 3.12.2015)

2. National Strategy for Social Integration for Poland, source: http://www.mpips.gov.pl/ gfx/mpips/userfiles/File/mps/NSIS.pdf (access: 1.12.2015).

3. Piekot T., Report on focused research - professional identity of the deaf and their problems in the labor market, Project co-financed by EU within EFS, proj. no. WND-PKOL.06.02.0002-109/11, source: http://www.glusiwpracy.dobrekadry.pl/dokumenty/Opracowanie_jakosciowe.pdf (access: 15.12.2015 r.)

4. Guidance on the implementation of support for the socially excluded and disadvantaged under the Operational Programme Human Capital Department of ESF Management at the Ministry of RD, Warsaw, October 2009, source: http://www.efs.gov.pl/dzialaniapromocyjne/ Documents/Poradnik_dot_realizacji_wsparcia_dla_os_wykluczonych_spol_POKL_ 091009.pdf (access: 05.12.2015)

5. Report on the disabled in Poland, Biuro Prasowe Kongresu Kobiet, Warsaw, 06.06.2011, source http://samorzad.pap.pl/palio/html.run?_Instance=samorzad_nowy.pap.pl\&_ PageID=6\&_media_id=57272\&_filename=KK_2011_06.06_raport_o_niepelnosprawnych. pdf\&_mimetype=application/pdf\&_CheckSum=780010585 (access: 3.12 .2015 ). 
6. Report of the Central Statistical Office on the Polish population health status in 2009, source: http://old.stat.gov.pl/cps/rde/xbcr/gus/ZO_stan_zdrowia_2009.pdf, s. 265 (access: 3.12.2015).

7. Consensus on the treatment of hearing loss using implants anchored in the bone, source: http://www.otolaryngologia.org.pl/orl2/pdf/konsensus_leczenie_niedosluchow_implanty_ zakotwiczone.pdf (access: 12.12.2015).

8. http://www.niepelnosprawni.gov.pl/niepelnosprawnosc-w-liczbach-/dane-demograficzne/ informacje-i-dane-demograficzne/ (access: 3.12.2015).

9. http://pedagogikaspecjalna.tripod.com/notes/deafness.html\#1 (access: 1.12.2015).

10. Report published on: http://old.stat.gov.pl/cps/rde/xbcr/gus/ZO_stan_zdrowia_2009.pdf, p. 74 (access: 3.12.2015).

11. http://www.uke.gov.pl/urzad-805 (access: 15.12.2014)

\title{
DOSTEPNOŚĆ SYSTEMU POWIADAMIANIA RATUNKOWEGO DLA OSÓB ZAGROŻONYCH WYKLUCZENIEM SPOŁECZNYM NA PRZYKŁADZIE OSÓB NIESŁYSZĄCYCH W POLSCE
}

\begin{abstract}
Wdrażany w Polsce od roku 2011 system powiadamiania ratunkowego oparty jest przede wszystkim na bezpośrednim, telefonicznym, werbalnym kontakcie pomiędzy osobą dokonującą zgłoszenia a operatorem numeru alarmowego w Centrum Powiadamiania Ratunkowego (CPR), oficerem dyżurnym w komendzie powiatowej Policji albo komendzie powiatowej Państwowej Straży Pożarnej, lub dyspozytorem ratownictwa medycznego. To sprawia, że przy takich założeniach staje się on niedostępny dla osób niesłyszących. Takie osoby nie mogą nawiązać kontaktu werbalnego z operatorem numeru alarmowego. Nawet, jeśli w codziennym życiu potrafią wypowiadać słowa i porozumiewać się z bezpośrednim rozmówcą dzięki umiejętności czytania z ruchu jego warg, to poprzez niemożność słyszenia kontakt telefoniczny staje się niemożliwy. Osoba niesłysząca może nawiązać kontakt i wymieniać informacje albo za pośrednictwem wzroku i komunikacji w języku migowym, albo za pomocą przekazu pisanego. Wobec powszechnego użycia, także w środowisku osób niesłyszących telefonów komórkowych pojawia się możliwość wykorzystywania do wysyłania zgłoszeń alarmowych krótkich wiadomości tekstowych, tzw. esemesów ${ }^{39}$. Autor w niniejszym artykule przedstawia swoje doświadczenia i wynikające z nich przemyślenia dotyczące powiadamiania ratunkowego i możliwości wykorzystania jego funkcjonalności przez osoby niepełnosprawne słuchowo. Doświadczenia były zbierane przy okazji aktywnego udziału autora w działaniach związanych $\mathrm{z}$ tworzeniem systemu powiadamiania ratunkowego na terenie województwa podkarpackiego oraz wdrażaniem w roku 2014 przez Centrum Powiadamiania Ratunkowego w Rzeszowie bramki SMS przeznaczonej do odbierania zgłoszeń alarmowych od osób niesłyszących z terenu województwa podkarpackiego.
\end{abstract}

Słowa kluczowe: CPR, SMS, system powiadamiania ratunkowego, SPR, głuchota.

DOI: $10.7862 / \mathrm{rz} .2018 . \mathrm{mmr} .17$

Tekst złożono $w$ redakcji: listopad $2017 \mathrm{r}$.

Przyjęto do druku: czerwiec 2018 r.

${ }^{39}$ Ang. SMS - short message service. 